\title{
Suitability of SWAT Model for Sediment Yields Modelling in the Eastern Africa
}

\author{
Preksedis Marco Ndomba ${ }^{1}$ and Ann van Griensven ${ }^{2}$ \\ ${ }^{1}$ University of Dar es Salaam, Dar es Salaam, \\ ${ }^{2} U N E S C O-I H E$, Institute for Water Education, Delft, \\ ${ }^{1}$ Tanzania \\ ${ }^{2}$ Netherlands
}

\section{Introduction}

Sediment yield refers to the amount of sediment exported by a basin over a period of time, which is also the amount that will enter a reservoir located at the downstream limit of the basin (Morris and Fan, 1998). The subject of sediment yield modelling has attracted the attention of many scientists but lack of data, resources and widely accepted methods to predict/estimate sediment yields are some of the barriers against this direction of research (Summer et al., 1992; Wasson 2002; Lawrence et al., 2004; Ndomba, 2007; Ndomba et al., 2005, 2008b, 2009; Shimelis et al., 2010).

The sediment yield model evaluated in this paper is the Soil and Water Assessment Tool (SWAT). It is hypothesized in the presented study cases that distributed and process based mathematical models such as SWAT could be a potential tool in predicting and estimating sediment yield especially at a catchment scale. Application of the distributed and processbased models could minimize the uncertainty resulting from assuming lumped, stationary and linear systems. Besides, the SWAT model has particular advantages for the study of basin change impacts and applications to basins with limited records (Bathurst, 2002; Ndomba, 2007). In principle, their parameters have a physical meaning and can be measured in the field, and therefore model validation can be concluded on the basis of a short field survey and a short time series of meteorological and hydrological data (Bathurst, 2002).

SWAT was originally developed by the United States Department of Agriculture (USDA) to predict the impact of land management practices on water, sediment and agricultural chemical yields in large ungauged basins (Arnold et al., 1995). The SWAT model has a long modelling history since it incorporates features of several Agriculture Research Service (ARS) models (Neitsch et al., 2005). The SWAT model is a catchment-scale continuous time model that operates on a daily time step with up to monthly/annual output frequency. The major components of the model include weather, hydrology, erosion, soil temperature, plant growth, nutrients, pesticides, land management, channel and reservoir routing. It divides a catchment into subcatchments. Each subcatchment is connected through a stream channel and further divided into a Hydrologic Response Unit (HRU). The HRU is a unique combination of a soil and vegetation types within the subcatchment. Sediment yield is estimated for each HRU with the Modified Universal Soil Loss Equation (MUSLE) (Williams, 1975) (Equation 1). 


$$
\text { Sed }=11.8\left(Q_{\text {surf }} q_{\text {peak }} \text { Area }{ }_{\text {hru }}\right)^{0.56} K_{\text {USLE }} C_{\text {USLE }} P_{\text {USLE }} L S_{\text {USLE }} \text { CFRG }
$$

Where Sed is defined as Sediment yield rate (tones/day), $Q_{\text {surf }}$ is the surface runoff volume $\left(\mathrm{mm} /\right.$ day), $q_{\text {peak }}$ is the peak runoff rate $\left(\mathrm{m}^{3} / \mathrm{s}\right)$, Area $a_{h u}$ is the area of the HRU (ha), $K_{U S L E}$ is the USLE soil erodibility factor $\left(0.013\right.$ metric ton $\mathrm{m}^{2} \mathrm{hr} /\left(\mathrm{m}^{3}\right.$-metric ton $\left.\left.\mathrm{cm}\right)\right)$, CUSLE is the USLE crop management factor or cover management factor, $P_{\mathrm{USLE}}$ is the USLE support practice factor, LS USLE is the USLE topographic factor, and CFRG is the coarse fragment factor.

The runoff component of the SWAT model supplies estimates of runoff volume and peak runoff rate using the curve number method (SCS, 1972) and modified rational method, respectively, which, along with the subbasin area, are used to calculate the runoff erosive energy variable. The crop management factor or cover management factor is recalculated every day that runoff occurs. It is a function of above-ground biomass, residue on the soil surface and the minimum cover factor for the plant. The $\mathrm{K}_{\text {USLE }}$ factor is estimated using an equation proposed by Mulengera and Payton (1999) for tropics. Other factors of the erosion equation are estimated as described by Neitsch et al. (2005). The current version of the SWAT model uses the simplified stream power equation of Bagnold's (1977) to route sediment in the channel. The maximum amount of sediment that can be transported from a reach segment is a function of the peak channel velocity. Sediment transport in the channel network is a function of two processes, degradation and aggradation (i.e. deposition), operating simultaneously in the reach (Neitsch et al., 2005).

The SWAT model includes an automated calibration procedure. The calibration procedure is based on the Shuffled Complex Evolution-University of Arizona algorithm (SCE-UA) as proposed by Duan et al. (1992). The autocalibration option in SWAT provides a powerful, labour saving tool that can be used to substantially reduce the frustration and uncertainty that often characterizes manual calibration (Van Liew et al, 2005). In one of the study cases other calibration tools such as the 'Sequential Uncertainty Fitting Algorithm' (SUFI-2) program (Abbaspour et al., 2004, 2007) were used.

Although general SWAT applications have shown that the model performs satisfactorily (Ndomba and Birhanu, 2008), its suitability for specific applications such as sediment yield modelling has yet to be ascertained. In this paper, various sediment yield modelling issues involved with using SWAT such as data requirements and analysis, calibration, sensitivity and uncertainty are critically evaluated in three well-studied cases, the Nyumba Ya Mungu (NYM) Reservoir subcatchment located in the upstream part of the Pangani River catchment (PRC), (a trans-boundary catchment shared between Kenya and Tanzania); the Simiyu River catchment (SRC), (a Lake Victoria Basin subcatchment in Tanzania); and the Koka Reservoir catchment (KRC) in Ethiopia. Growing population, growing demand of cultivated land, mostly inaccurate traditional land usage and dangerously increasing deforestation have increased soil erosion. Erosion has a major impact on nature and diminished the agriculture potential of the selected study cases. Excessive exploitation increases the susceptibility of the soil to fluvial and upland erosion, which is responsible for the increased sediment transport and deposition into the reservoirs.

\section{Materials and methods}

\subsection{Description of the study cases}

Case study 1, the Koka Reservoir catchment (KRC) lies within the western part of the Awash Basin and has an area of approximately 11,000 km² (Figure 1(a-d) \& Table 1). The Awash 
River begins in the Central Ethiopian Highlands at an altitude of $3000 \mathrm{~m}$ to the west of Addis Ababa. After flowing through Koka Reservoir, it flows northeastwards along the rift valley until eventually discharging into Lake Abbe. The Koka Reservoir is situated about 90 $\mathrm{km}$ southeast of Addis Ababa at a longitude of $39^{\circ} 10^{\prime} \mathrm{E}$ and latitude of $8^{\circ} 25^{\prime} \mathrm{N}$. The erosion rates in the KRC and in the Awash Basin as a whole are high with values generally exceeding $6,000 \mathrm{t} / \mathrm{km}^{2} / \mathrm{yr}$ and occasionally as high as $20,000 \mathrm{t} / \mathrm{km}^{2} / \mathrm{yr}$.

The climate of the Awash Basin is characterized by the Inter-Tropical Convergence Zone (ITCZ). The Mean annual rainfall (MAR) and temperature vary spatially across the catchment between 170 and $1978 \mathrm{~mm} /$ annum and 12.8 and $31.5^{\circ} \mathrm{C}$, respectively. The area is dominated by a bimodal rainfall pattern. According to the National Meteorological Services Agency, the study area is characterized by a quasi-double maxima rainfall pattern with a small peak in April and maximum peak in August. The rainfall in the highlands shows a strong correlation with altitude (Lemma, 1996). The mean annual wind speed in the KRC is $1.9 \mathrm{~m} / \mathrm{s}$.

Two major relief features are found in the Awash Basin: the highlands of the Ethiopian Plateau and the lowlands of the Rift Valley. The bedrock and soil in the area determine the amount and composition of transported sediments in the river. The geology of the basin is dominated by sedimentary rocks such as limestone and sandstone. The alluvium deposits consist of clay, sand and tuff. The long rains occur between June and September.

Case study 2, the Nyumba Ya Mungu (NYM) Reservoir subcatchment, has runoff that is highly regulated by the man-made Nyumba Ya Mungu (NYM) Reservoir of some $140 \mathrm{~km}^{2}$. The NYM Reservoir subcatchment is located in the upstream part of Pangani River catchment (PRC) (Figure 1 \& Table 1). The PRC is located between coordinates 36 $20^{\prime} \mathrm{E}$,

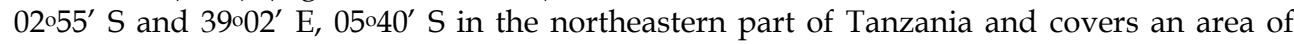
about 42,200 km², with approximately $5 \%$ in Kenya (Figure 1). The Pangani River has two main tributaries, the Kikuletwa (1DD1) and the Ruvu (1DC1) (Figure 1), which join at the Nyumba Ya Mungu (NYM) reservoir.

The catchment of NYM occupies a total land and water area of about $12,000 \mathrm{~km}^{2}$ (Ndomba, 2007). It is located between coordinates 36 $20^{\prime} 00^{\prime \prime} \mathrm{E}, 3^{\circ} 00^{\prime} 00^{\prime \prime} \mathrm{S}$ and $38^{\circ} 00^{\prime} 00^{\prime \prime} \mathrm{E}, 4^{\circ} 3^{\prime} 50^{\prime \prime} \mathrm{S}$. This area has a Mean Annual Rainfall (MAR) of about 1000 mm/annum. The rainfall pattern is bimodal with two distinct rainy seasons, long rains from March to June and short rains from November to December. Rohr and Killingtveit (2003) indicated that the maximum precipitation on the southern hillside of Mt. Kilimanjaro takes place at about 2,200 m.a.s.l., which is $400-500 \mathrm{~m}$ higher than previously assumed. The mean annual wind speed is 1.87 $\mathrm{m} / \mathrm{s}$. The altitude in the study area ranges from 700 and 5,825 m.a.s.l. with the peak of Mt. Kilimanjaro as the highest ground. Based on the Soil Atlas of Tanzania, the main soil type in the study area is clay with good drainage (Hathout, 1983). The landcover of the catchment is dominated by actively-induced vegetation, forest, bushland and thickets with some alpine desert. The majority of the population in the basin directly or indirectly depends on irrigated agriculture. Agriculture is concentrated in the highlands with area coverage less than $20 \%$ (Ndomba, 2007). Lowlands are better suited for pastoralism. The main runoffsediment generating subcatchments in the study area upstream of NYM reservoir are Weruweru, Kikafu, Sanya, Upper Kikuletwa and Mt. Meru. The basin is also important for hydropower generation, which is connected to the national grid. Hydropower plants, which are downstream of NYM Reservoir are NYM (8 MW), Hale (21 MW), and New Pangani falls (66 MW). 


\begin{tabular}{|c|c|c|c|c|c|}
\hline Case study & $\begin{array}{l}\text { Catchment } \\
\text { area } \\
\left(\mathrm{km}^{2}\right)\end{array}$ & Topography & Land use/cover & $\begin{array}{l}\text { Geology and } \\
\text { Soil type }\end{array}$ & Climate \\
\hline $\begin{array}{l}\text { Nyumba Ya } \\
\text { Mungu } \\
\text { (NYM) } \\
\text { Reservoir } \\
\text { catchment } \\
\text { in the } \\
\text { upstream } \\
\text { part of the } \\
\text { Pangani } \\
\text { River } \\
\text { catchment }\end{array}$ & 12,000 & $\begin{array}{l}\text { Plains - } \\
\text { mountainous }\end{array}$ & $\begin{array}{l}\text { Actively } \\
\text { induced } \\
\text { vegetation, } \\
\text { forest, bushland } \\
\text { and thickets } \\
\text { with some } \\
\text { alpine desert } \\
\text { and agricultural } \\
\text { land for } \\
\text { farming }\end{array}$ & $\begin{array}{l}\text { Neogene } \\
\text { Volcanic and pre- } \\
\text { Cambrian } \\
\text { metamorphic } \\
\text { rocks extensively } \\
\text { covered by } \\
\text { superficial } \\
\text { Neogene deposits } \\
\text { including } \\
\text { calcareous } \\
\text { tuffaceosus; Clay } \\
\text { with moderate to } \\
\text { good drainage }\end{array}$ & $\begin{array}{l}\text { Semi arid - } \\
\text { humid }\end{array}$ \\
\hline $\begin{array}{l}\text { Koka } \\
\text { Reservoir } \\
\text { catchment } \\
(\text { KRC) }\end{array}$ & 11,000 & Rugged & $\begin{array}{l}\text { Agricultural } \\
\text { land for } \\
\text { farming, Acacia } \\
\text { and eucalyptus } \\
\text { trees are } \\
\text { prevailing ones }\end{array}$ & $\begin{array}{l}\text { Sedimentary } \\
\text { rocks such as } \\
\text { limestone and } \\
\text { sandstone; clay, } \\
\text { sand and tuff }\end{array}$ & Tropical \\
\hline $\begin{array}{l}\text { Simiyu } \\
\text { River } \\
\text { catchment } \\
(\text { SRC) }\end{array}$ & 10,659 & Relatively flat & $\begin{array}{l}\text { Agricultural } \\
\text { land for } \\
\text { farming, } \\
\text { grassland for } \\
\text { grazing, and } \\
\text { bushland. }\end{array}$ & $\begin{array}{l}\text { Dominated by } \\
\text { Precambrian } \\
\text { rocks and some } \\
\text { quaternary } \\
\text { sediments; There } \\
\text { are also some } \\
\text { extensive areas } \\
\text { overlain by recent } \\
\text { alluvial deposits; } \\
\text { sandy loam } \\
\text { covers a large } \\
\text { part of the } \\
\text { catchment }\end{array}$ & $\begin{array}{l}\text { Warm } \\
\text { tropical } \\
\text { savannah } \\
\text { climate/ } \\
\text { Diverse } \\
\end{array}$ \\
\hline
\end{tabular}

Table 1. Major characteristics of the three study cases in Eastern Africa

Case study 3, the Simiyu River catchment (SRC), is located in the northern part of Tanzania southeast of Lake Victoria (Figure 1 \& Table 1). It covers an area of $10,659 \mathrm{~km}^{2}$ and is located between the coordinates $33^{\circ} 15^{\prime} 00^{\prime \prime} \mathrm{E}, 02^{\circ} 30^{\prime} 00^{\prime \prime} \mathrm{S}$ and $35^{\circ} 00^{\prime} 00^{\prime \prime} \mathrm{E}, 03{ }^{\circ} 30^{\prime} 00^{\prime \prime} \mathrm{S}$. The SRC is occupied by about one million inhabitants. The catchment is mainly covered by agricultural land for farming, grassland for grazing, and bushland. The Simiyu River flows from the Serengeti National Park Plains to Lake Victoria in the downstream region. The two major tributaries of the Simiyu River are Simiyu-Duma and Simiyu-Ndagalu and they merge shortly before the Simiyu River enters Lake Victoria. The river is characterized as ephemeral 
(Ndomba et al., 2005) and normally stays dry in the months of August, September and October. During the long rainy season, discharge from the river reaches as high as $331 \mathrm{~m}^{3} / \mathrm{s}$.

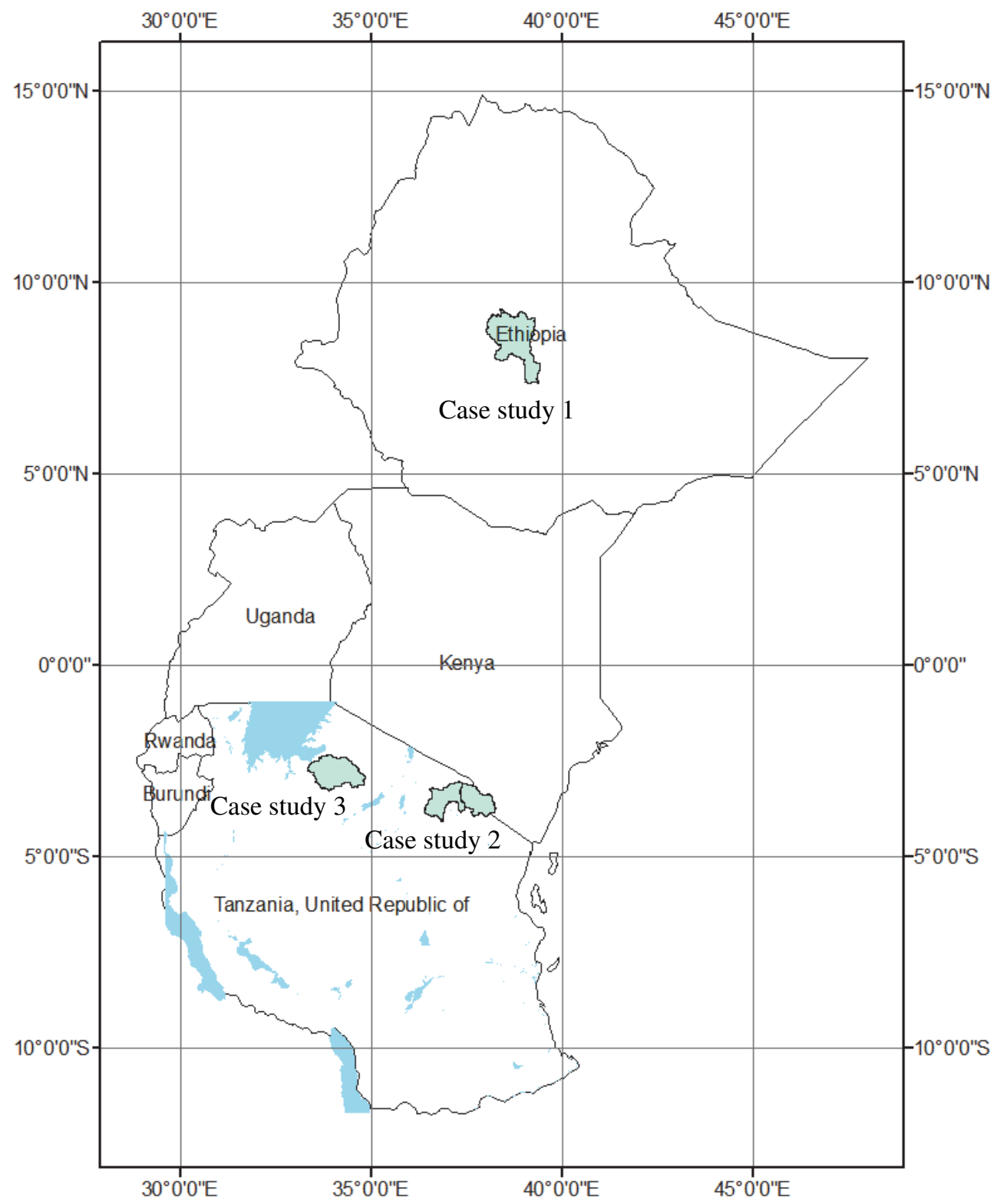

Fig. 1a. A map showing the three case studies in Eastern Africa 


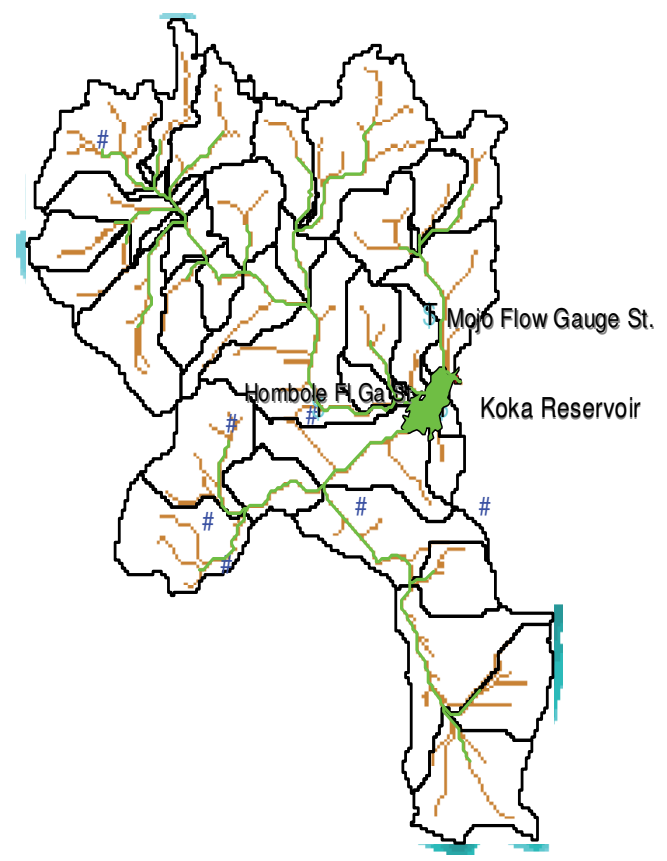

- Rainfall stations

Flows stations

Koka Reservoir

Rivers

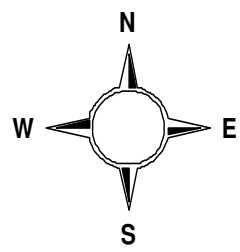

Fig. 1b. A location map of Case study 1, Koka Reservoir catchment (KRC), as adopted from Endale(2008)

The catchment has a warm tropical savannah climate with an average temperature of about $23^{\circ} \mathrm{C}$. The total average annual precipitation varies between 700 and $800 \mathrm{~mm} /$ annum. The mean annual wind speed is $1.60 \mathrm{~m} / \mathrm{s}$. The SRC is considered to be one of the main contributors to the deterioration of water quality (i.e., sediments and nutrients) in the Lake Victoria. This is because of its relatively large size, its large inflow contribution and its many agricultural activities using agrochemicals which generate high yields of sediments. 


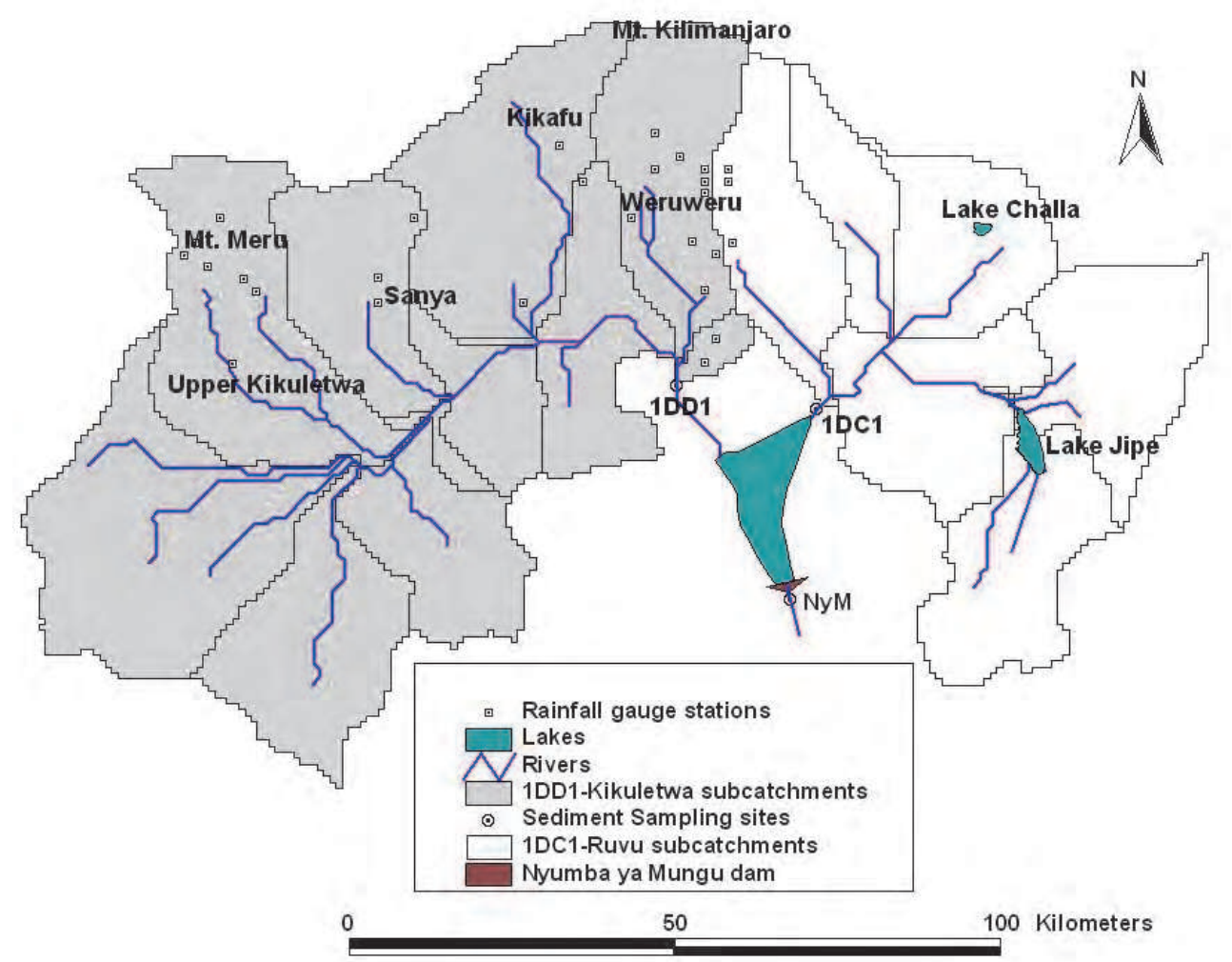

Fig. 1c. A location map of Case study 2, Nyumba Ya Mungu Reservoir, in the upstream part of the Pangani River catchment as adopted from (Ndomba, 2007) 


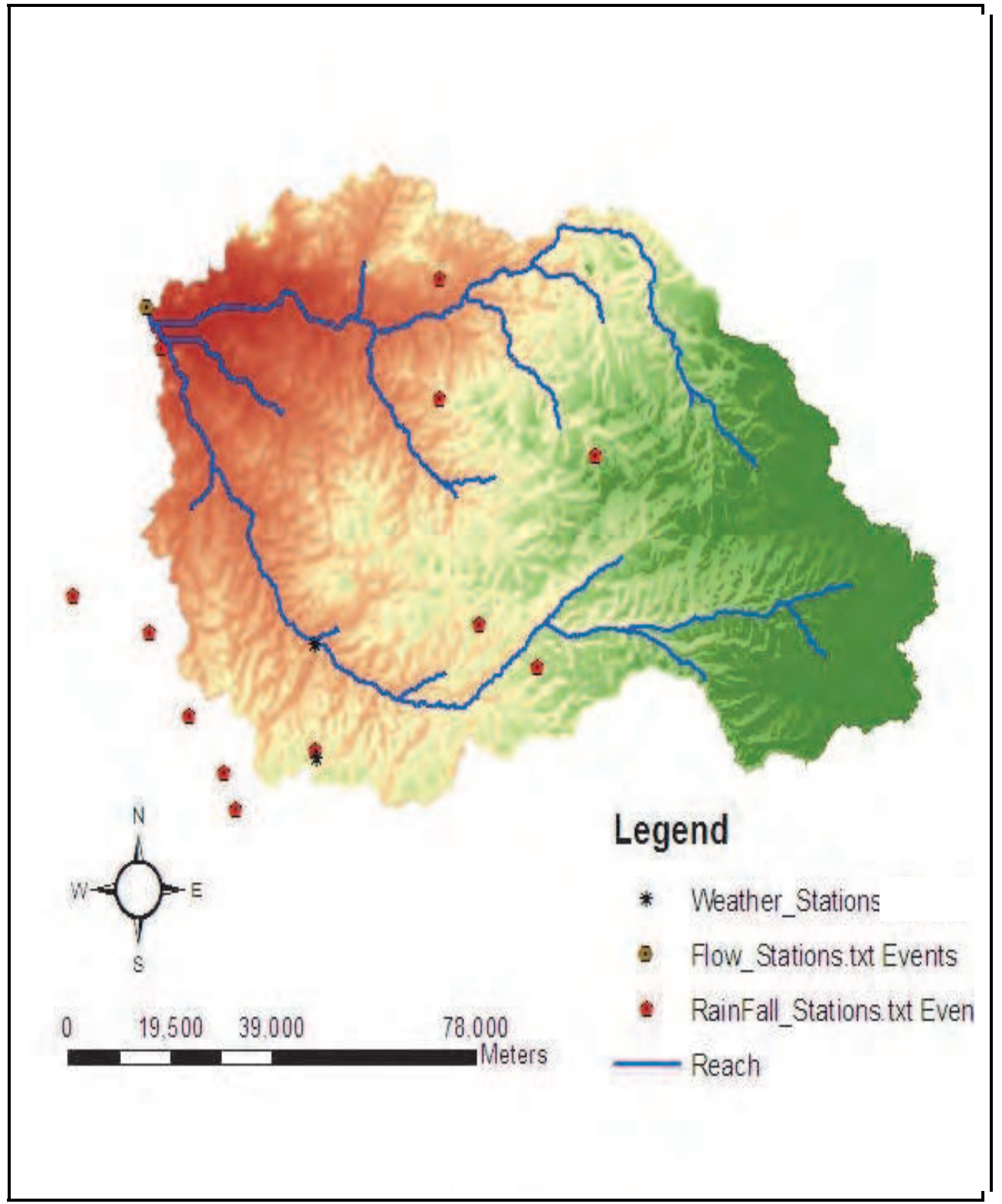

Fig. 1d. A location map of Case study 3, Simiyu River catchment, Tanzania as adopted from Abdelhamid (2010)

\subsection{SWAT concept}

The SWAT model uses the Modified USLE (MUSLE) equation developed by Williams (1975) (Equation 1) to simulate the sediment yield from the upland catchments (Neitsch et al., 
2005). The surface runoff $\left(Q_{\text {surf }}\right)$ as input to the MUSLE equation is simulated by the runoff component of SWAT. The SWAT model uses water balance Equation 2 as a driving force behind everything that happens in the watershed (Neitsch et al., 2005).

$$
S W_{t}=S W_{t-1}+\sum_{i=1}^{t}\left(R_{\text {day_i }}-Q_{\text {surf_i }}-E_{a_{-} i}-w_{\text {seep_ } i}-Q_{g w_{-} i}\right)
$$

$\mathrm{SW}_{\mathrm{t}}$ is the final soil water content $(\mathrm{mm}), \mathrm{SW}_{\mathrm{t}-1}$ is the initial soil water content on day $\mathrm{i}(\mathrm{mm})$, $t=1,2,3, \ldots, n$ where " $n$ " is the total number of days during the simulation (days), $R_{\text {day } \_i}$ is the amount of precipitation on day $i(\mathrm{~mm}), Q_{\text {surf } \_i}$ is the amount of surface runoff on day $i$ $(\mathrm{mm}), \mathrm{E}_{\mathrm{a}_{-} \mathrm{i}}$ is the amount of evapotranspiration on day $\mathrm{i}(\mathrm{mm}), \mathrm{W}_{\text {seep_i }}$ is the amount of water entering the vadose zone from the soil profile on day $i(\mathrm{~mm})$, and $Q_{g_{-} i}$ is the amount of return flow on day i ( $\mathrm{mm})$.

SWAT uses Manning's equation to define the rate and velocity of flow. Water is routed through the channel network using the variable storage routing method or the Muskingum River routing method. Both the variable storage and Muskingum routing methods are variations of the kinematic wave model (Neitsch et al., 2005).

\subsection{Data and data analysis}

The sediment flow data are readily available (Table 2a-c). The quality and adequacy of data varies from one catchment to the other. In the two study cases, the Simiyu River and Koka Reservoir catchments, secondary data on streams flows, climate, sediment flow and spatial data were used to setup, calibrate and validate the model. These are typical data types used in most of the SWAT applications elsewhere in the region (Andualem and Yonas, 2008; Shimelis et al., 2010). Most of the sediment flow data are intermittent instantaneous sediment flow data. In one of the cases, the NYM Reservoir subcatchment, primary data on sediment flow was collected to complement the analysis. These are continuous subdaily sediment concentrations data plus multi-temporal reservoir survey information. As Table 2 stipulates, various sources of data were explored. The data preparation and analysis task involved analyzing statistics such as season mean, percent missing data, identifying outliers, length of the records, temporal and spatial variability of rainfall, and wet years' period. The wet years' period is defined as the period when the annual total rainfall is above the long term annual average. The analysis was meant to guide and provide data for the SWAT modelling. For instance, spatial variability justified the need for distributed modelling. The derived statistics were also used as inputs to weather generator module of SWAT. The module generates climatic data or fills in gaps in measured records. As presented in Tables 2a-1, 2b-1 and 2c-1, the input spatial data included base maps such as readily available topographic maps in the Ministries and global spatial thematic maps (i.e. Digital Elevation Models, DEM; Soil, and Landuse-cover) of various resolutions. One of the case studies reviewed in this paper (Mulungu and Munishi, 2007), used high-resolution data on land use from the $30 \mathrm{~m}$ LandSat TM Satellite, the $90 \mathrm{~m}$ Digital Elevation Model and the Soil and Terrain Database for Southern Africa (SOTERSAF). In some cases such as NYM, the soil types were extracted from Pauw (1984) digital map and complemented by the Soil Atlas of Tanzania (Hathout, 1983). Similarly, climatic data included rainfall data from the regular ground monitoring network. 


\begin{tabular}{|c|c|c|c|c|c|c|c|}
\hline \multirow[t]{2}{*}{ SN } & \multirow{2}{*}{ Data type } & \multirow{2}{*}{$\begin{array}{c}\text { No. of } \\
\text { stations }\end{array}$} & \multirow{2}{*}{$\begin{array}{c}\text { Data } \\
\text { availability }\end{array}$} & \multirow{2}{*}{$\begin{array}{c}\% \\
\text { missing }\end{array}$} & \multirow{2}{*}{ Source } & \multicolumn{2}{|c|}{ Resolution } \\
\hline & & & & & & Spatial & Temporal \\
\hline 1. & Rainfall & 31 & $1922-2005$ & $1-60$ & $\begin{array}{l}\text { MoWI/ } \\
\text { TMA/PBWO }\end{array}$ & - & $\begin{array}{l}\text { Daily/ } \\
\text { hourly }\end{array}$ \\
\hline & Climate & 9 & 1958-1999 & $0.1-62$ & $\begin{array}{l}\text { MoWI/ } \\
\text { TMA/PBWO }\end{array}$ & - & Daily \\
\hline 2. & Flows & 3 & $1952-2005$ & $1-54$ & MoWI/ /PBWO & - & Daily \\
\hline 3. & DEM & - & 2006 & - & USGS/ HDRO 1K & $1 \mathrm{~km}$ & - \\
\hline 4. & Landuse & & 1990’s & - & IRA/Landsat & $30 \mathrm{~m}$ & - \\
\hline 5. & Soil & - & $1983-1984$ & - & $\begin{array}{l}\text { Pauw(1984) \& } \\
\text { Hathout, (1983) }\end{array}$ & - & - \\
\hline 6. & $\begin{array}{l}\text { Sediment } \\
\text { load }\end{array}$ & 3 & $2005-2006$ & 0 & UDSM & - & $\begin{array}{l}\text { Subdaily } \\
\text { continuou } \\
\text { s }\end{array}$ \\
\hline 7. & $\begin{array}{l}\text { Reservoir } \\
\text { bed } \\
\text { contour }\end{array}$ & 1 & $\begin{array}{l}1968 \& \\
2005\end{array}$ & - & UDSM & $1.53 / 1.0 \mathrm{~m}$ & 37 years \\
\hline
\end{tabular}

Table 2a-1. Data types and sources for the Nyumba Ya Mungu Reservoir catchment located in the upstream part of the Pangani River catchment

Note: MoWI: Minstry of Water and Irrigation; TMA: Tanzania Meteorological Authority; PBWO: Pangani Basin Water Office; IRA: Institute of Resources Assessment based at University of Dar es Salaam (UDSM)

\begin{tabular}{|l|l|l|l|}
\hline \multicolumn{1}{|c|}{ Statistic } & \multicolumn{1}{|c|}{$\begin{array}{c}\text { Subdaily suspended } \\
\text { sediment concentration } \\
{[\mathrm{mg} / \mathrm{l}]}\end{array}$} & $\begin{array}{c}\text { Gauge Height } \\
{[\mathrm{m}]}\end{array}$ & \multicolumn{1}{|c|}{$\begin{array}{c}\text { Streamflow } \\
\text { discharge }\left[\mathrm{m}^{3} / \mathrm{s}\right]\end{array}$} \\
\hline No. Of data points & 291 & 291 & 291 \\
\hline Maximum & 9110.0 & 4.44 & 256.53 \\
\hline Minimum & 16.0 & 0.89 & 12.19 \\
\hline Mean & 282.5 & 1.32 & 34.79 \\
\hline $\begin{array}{l}\text { Standard Deviation, } \\
\text { STD }\end{array}$ & 801.7 & 0.49 & 30.02 \\
\hline $\begin{array}{l}\text { Coefficient of Variation, } \\
\text { Cv (\%) }\end{array}$ & 283.8 & 36.69 & 86.27 \\
\hline $\begin{array}{l}\text { Standard Error of the } \\
\text { Mean, SEM }\end{array}$ & 47.0 & 0.03 & 1.76 \\
\hline
\end{tabular}

Table 2a-2. A summary of sediment flow data for the Nyumba Ya Mungu Reservoir catchment in the upstream part of the Pangani River catchment as sampled between March 18 and November 10, 2005 by an ISCO 6712 machine at 1DD1 site 


\begin{tabular}{|l|l|l|l|l|l|}
\hline \multicolumn{1}{|c|}{ Statistic } & \multicolumn{1}{|c|}{$\begin{array}{c}\text { Suspended } \\
\text { sediment } \\
\text { concentrations } \\
{[\mathrm{mg} / \mathrm{l}]}\end{array}$} & $\begin{array}{c}\text { Base } \\
\text { Gauge } \\
\text { Height } \\
{[\mathrm{m}]}\end{array}$ & $\begin{array}{c}\text { Fall, } \\
{[\mathrm{m}]}\end{array}$ & $\begin{array}{c}\text { Stream } \\
\text { flow } \\
\text { discharge } \\
{\left[\mathrm{m}^{3} / \mathrm{s}\right]}\end{array}$ & $\begin{array}{c}\text { Sediment } \\
\text { load, } \\
\text { [t/day] }\end{array}$ \\
\hline No. Of data points & 288 & 288 & 288 & 288 & 288 \\
\hline Average & 54.9 & 0.724 & 0.098 & 4.025 & 19.1 \\
\hline Minimum & 2.8 & 0.420 & 0.025 & 2.885 & 1 \\
\hline Maximum & 830.0 & 2.270 & 0.190 & 12.227 & 359 \\
\hline Standard deviation & 75.5 & 0.28 & 0.014 & 1.12 & 34.91 \\
\hline $\begin{array}{l}\text { Standard Error of the } \\
\text { Mean (SEM) }\end{array}$ & 4.45 & 0.02 & 0.001 & 0.07 & 2.06 \\
\hline
\end{tabular}

Table 2a-3. Daily suspended sediment flow data for the Nyumba Ya Mungu Reservoir catchment in the upstream part of the Pangani River catchment at the 1DC1-Ruvu site sampled using DH-48 sampler sampled at 9.00 hrs between April 19, 2005 and January 31, 2006

Note: (1) Fall signifies measured water gauge height difference between Base and Auxiliary gauging stations; and (2) Stream flow discharge data were derived from complex rating curve (Ndomba, 2007).

\begin{tabular}{|c|c|c|c|c|c|c|c|}
\hline \multirow[t]{2}{*}{$\mathrm{SN}$} & \multirow{2}{*}{ Data type } & \multirow{2}{*}{$\begin{array}{l}\text { No. of } \\
\text { stations }\end{array}$} & \multirow{2}{*}{$\begin{array}{c}\text { Data } \\
\text { availability }\end{array}$} & \multirow{2}{*}{$\begin{array}{c}\% \\
\text { missing }\end{array}$} & \multirow{2}{*}{ Source } & \multicolumn{2}{|c|}{ Resolution } \\
\hline & & & & & & Spatial & Temporal \\
\hline 1. & Rainfall & 13 & 1928-2003 & $8.8-69.8$ & MoWI/ TMA & - & $\begin{array}{l}\text { Daily/ } \\
\text { hourly }\end{array}$ \\
\hline 2. & Climate & 2 & $1970-1984$ & $3.4-21$ & MoWI/ TMA & - & Daily \\
\hline 3. & Flows & 1 & $1969-2000$ & 46 & MoWI & - & Daily \\
\hline 4. & DEM & - & 2010 & - & ASTER & $30 \mathrm{~m}$ & - \\
\hline 5. & Landuse & & 2010 & - & GLCC & $1 \mathrm{~km}$ & - \\
\hline 6. & Soil & - & 2010 & - & $\begin{array}{l}\text { FAO/SOTER } \\
\text { SAF }\end{array}$ & $10 \mathrm{~km}$ & - \\
\hline 7. & $\begin{array}{l}\text { Sediment } \\
\text { load }\end{array}$ & 1 & 1999-2003 & 0 & UDSM & - & $\begin{array}{l}\text { Daily } \\
\text { intermi- } \\
\text { ttent }\end{array}$ \\
\hline
\end{tabular}

Table 2b-1. Data types and sources for the Simiyu River catchment

Note: ASTER: Advanced Space borne Thermal Emission and Reflection Radiometer; GLCC: Global Land Cover Charactersization; SOTERSAF: Soil Terrain Database for Southern Africa; FAO: Food and Agricultural Organization. 


\begin{tabular}{|l|l|l|l|l|}
\hline \multicolumn{1}{|c|}{ Statistic } & $\begin{array}{c}\text { Suspended } \\
\text { sediment } \\
\text { concentrations } \\
{[\mathrm{mg} / \mathrm{l}]}\end{array}$ & $\begin{array}{c}\text { Daily } \\
\text { Stream } \\
\text { flow } \\
\text { discharge } \\
{\left[\mathrm{m}^{3} / \mathrm{s}\right]}\end{array}$ & $\begin{array}{c}\text { Gauge } \\
\text { Height } \\
{[\mathrm{m}]}\end{array}$ & $\begin{array}{c}\text { Sediment } \\
\text { load, } \\
{[\mathrm{t} / \text { day }]}\end{array}$ \\
\hline No. & 102 & 70 & 13 & 70 \\
\hline Max & 5067 & 213 & 3.250 & 20,707 \\
\hline Min & 5.0 & 2.0 & 0.250 & 13.0 \\
\hline Mean & 981.0 & 19.925 & 1.813 & 2,615 \\
\hline Standard Deviation, STD & 1108.6 & 29.240 & 1.051 & 4,325 \\
\hline Coefficient of Variation, Cv (\%) & 113 & 146.748 & 57.949 & 165 \\
\hline $\begin{array}{l}\text { Standard Error of the Mean, } \\
\text { SEM }\end{array}$ & 109.8 & 3.495 & 0.291 & 517 \\
\hline
\end{tabular}

Table $2 \mathrm{~b}-2$. A summary of intermittent daily sediment flow data for the Simiyu River catchment as sampled between June 30, 1999 and May 29, 2004 at the Main Bridge site, the outlet

\begin{tabular}{|c|c|c|c|c|c|c|c|}
\hline \multirow{2}{*}{ SN } & \multirow{2}{*}{ Data type } & \multirow{2}{*}{$\begin{array}{c}\text { No. of } \\
\text { stations }\end{array}$} & \multirow{2}{*}{$\begin{array}{c}\text { Data } \\
\text { availability }\end{array}$} & \multirow{2}{*}{$\begin{array}{c}\% \\
\text { missing }\end{array}$} & \multirow{2}{*}{ Source } & \multicolumn{2}{|c|}{ Resolution } \\
\hline & & & & & & Spatial & Temporal \\
\hline 1. & Rainfall & 3 & 1990-2004 & $\begin{array}{l}0.12- \\
0.24\end{array}$ & NMSA & - & $\begin{array}{l}\text { Daily/ho } \\
\text { urly }\end{array}$ \\
\hline 2. & Climate & 4 & 1990-2004 & $\begin{array}{l}1.32- \\
1.42\end{array}$ & NMSA & - & Daily \\
\hline 3. & Flows & 3 & 1990-2004 & $\begin{array}{l}0.15- \\
0.27\end{array}$ & DH-MoWR & - & Daily \\
\hline 4. & DEM & & 2008 & - & $\begin{array}{l}\text { USGS/ } \\
\text { HDRO 1K }\end{array}$ & $1 \mathrm{~km}$ & - \\
\hline 5. & Landuse & & 2008 & - & GLCC & $1 \mathrm{~km}$ & - \\
\hline 6. & Soil & & 2008 & - & $\begin{array}{l}\text { FAO/SOTE } \\
\text { RSAF }\end{array}$ & $10 \mathrm{~km}$ & - \\
\hline 7. & $\begin{array}{l}\text { Sediment } \\
\text { load }\end{array}$ & 3 & 1990-2004 & $2.2-2.8$ & DH-MoWR & - & $\begin{array}{l}\text { Daily } \\
\text { intermitte } \\
\text { nt }\end{array}$ \\
\hline 8. & $\begin{array}{l}\text { Reservoir } \\
\text { bed } \\
\text { contour }\end{array}$ & & $\begin{array}{l}1959,1981, \\
1988,1999\end{array}$ & - & DH-MoWR & - & $\begin{array}{l}22,7,11 \\
\text { years, } \\
\text { respective } \\
\text { ly }\end{array}$ \\
\hline
\end{tabular}

Table 2c-1. Data types and sources for the Koka Reservoir catchment Note: DH-MoWR: Department of Hydrology, Ministry of Water Resources, Ethiopia; NMSA: National Meteorological Service Agency, Ethiopia; and “_" Not applicable. 


\begin{tabular}{|l|l|l|}
\hline \multicolumn{1}{|c|}{ Statistic } & \multicolumn{1}{|c|}{$\begin{array}{c}\text { Mean monthly Stream } \\
\text { flow discharges } \\
{\left[\mathrm{m}^{3} / \mathrm{s}\right]}\end{array}$} & \multicolumn{1}{|c|}{$\begin{array}{c}\text { Sediment load, } \\
\text { [t/month] }\end{array}$} \\
\hline No. & 180 & 180.00 \\
\hline Max & 421.930 & 179,841 \\
\hline Min & 1.000 & 200 \\
\hline Mean & 47.710 & 12,596 \\
\hline Standard Deviation, STD & 78.010 & 18,178 \\
\hline Coefficient of Variation, Cv (\%) & 163.510 & 144 \\
\hline Standard Error of the Mean, SEM & 5.810 & 1355 \\
\hline
\end{tabular}

Table 2c-2. A summary of continuous monthly sediment flow data for the Koka Reservoir catchment for the period from January 1990 to December 2004 at the Koka Reservoir as adopted from Endale (2008)

\subsection{SWAT model applications procedures and assumptions}

It should be noted that SWAT, if not properly applied, may result in parameter uncertainty problems. Therefore, elaboration of the rationale of each application step is necessary.

In these study cases the model was set up to represent the spatial variability of the main runoff-sediment yield controlling features such as soils, land use/cover, terrain (i.e, slope and slope length), river channels and reservoirs. The distributed nature of the sediment yield and erosion representation (lumped, semi and fully distributed) depended on the availability of data and computation resources.

The Latin Hypercube One-factor-At-a-Time (LH-OAT) design as proposed by Morris (1991) implemented in SWAT was used as a sensitivity analysis tool. Sensitivity analysis of hydrology and sediment transport components parameters were conducted without and/or with observed data before and after calibration. Various lengths of simulations (i.e. 2, 4, 6, 8 yrs and greater) were tested in order to capture model input (i.e., parameter and data) uncertainty. These analyses were used to identify the sensitive parameters.

Manual calibration, expert knowledge and automatic calibration techniques were tested for the calibration procedures. The autocalibration routine based on the Shuffled Complex Evolution-University of Arizona (SCE-UA) that is incorporated in the SWAT model has been used very often (Duan et al., 1992). In one of the study cases, SRC, the SUFI-2 program which combines calibration and uncertainty analysis (Abbaspour et al., 2004, 2007) was used. This tool is widely used in the region (Shimelis et al., 2010). The sensitive model parameters were adjusted within their feasible ranges during calibration to minimize model prediction errors for daily and monthly flow and sediment loads. In one of the study cases, i.e. the NYM Reservoir catchment, soil erodibility (K $\mathrm{K}_{\text {USLE}}$ ) (a MUSLE factor) was estimated according to the equation proposed by Mulengera and Payton (1999) for tropics. Biascorrected rating curves were developed and used to interpolate or extrapolate sediment loads (Ndomba et al., 2008b). It should be noted that to date there is no consensus on how to develop an excellent rating curve, especially from a short period of records. Ndomba et al. (2008b) developed the rating curve from continuous subdaily suspended sediment data (i.e. 2 to 12 samples a day) collected by an automatic pumping sampler (ISCO 6712). The ISCO 6712 sampler data were calibrated by daily-midway and intermittent-cross section sediment samples collected by a depth-integrating sampler (D-74). The sediment loads from rating 
curve were bias corrected. Sediment load correction factors were derived from both statistical bias estimators (Ferguson, 1986) and actual sediment load approaches (Ndomba et al., 2008a). It was important to do this as it is known that uncorrected rating curves, developed by Ordinary Least Square (OLS) tend to underestimate sediment loads (Ferguson, 1986; Ndomba et al., 2008b). The SWAT model simulation was validated with long term reservoir sediment accumulation and/or sediment loads.

Parameter uncertainty in this study was reduced by placing emphasis on the most sensitive parameters and reformulating the model. This was achieved in one case by estimating some important parameters outside the model using proposed equations/estimators for the Eastern Africa and tropics. This approach was also suggested by Melching (1995). In some cases, the degree of parameter estimation uncertainty of the catchment sediment yield model was reduced by calibrating the parameters during the wet years' period for which most of the hydro-climatic and sediment flow data required by the model are available, as suggested by Yapo, et al., (1996) who observed that the hydrographs of wet years produce more identifiable parameters.

The performance of the model using filled and raw rainfall was evaluated in order to assess input data uncertainty (Ndomba et al., 2008b). Model performances were mainly evaluated based on Nash-Sutcliffe Coefficient of Efficiency (CE), Relative Error (RE), and Total Mass Balance Controller (TMC). CE provides a normalized estimate of the relationship between the observed and predicted model values. The simulation results were considered good for $\mathrm{CE}$ values greater than 0.75 , while for values of efficiency between 0.75 and 0.36 the simulation results were considered to be satisfactory. $\mathrm{CE}$ values between 0.36 and 0 were considered to be fair. A value of zero would indicate that the fit was as good as using the average value of all the measured data. RE was estimated as the ratio of the absolute error to the true value and expressed in percentage. RE of less than twenty percent $(20 \%)$ is considered acceptable for most scientific applications.

SWAT applications in this study assume a number of things. Although the principal external dynamic agents of sedimentation are water, wind, gravity and ice (Vanoni, 1975) only the hydrospheric forces of rainfall, runoff and streamflow were considered. The computed sediment yield in SWAT is solely a result of sheet erosion processes in the catchment (Shimelis et al., 2010).

\section{Results and discussions}

\subsection{Sensitive parameters controlling sediment generation and routing}

Seven (7) out of nine (9) SWAT parameters that directly govern the sediment yield and transport in the study cases NYM, SRC and KRC were found to be sensitive (Table 3). It should be noted that rank 10 signifies that a parameter is not sensitive/influential at all. These parameters can be categorized into two groups: upland and channel factors. The former group includes parameters such as $\mathrm{P}_{\mathrm{USLE}}, \mathrm{C}_{\mathrm{USLE}}, \mathrm{K}_{\mathrm{USLE}}$, Biological mixing efficiency (BIOMIX), and Initial residual cover (RSDIN); whereas Linear re-entrainment parameter for channel sediment routing (Csp), Channel cover factor $(\mathrm{CCH})$, Channel erodibility factor $(\mathrm{KCH})$ and Exponential re-entrainment parameter for channel sediment routing (SPEXP) parameters belong to the latter group.

However, it should be noted that only channel routing parameters with serial numbers 1, 2, 4 , and 5 in the Table 3 were calibrated in all cases. As described in Neitsch et al. (2005), SWAT upland factors according to the MUSLE equation are formed based on regression 
analysis of runoff plots-based data. Mulengera and Payton (1999) attempted to define KUSLE values for tropical regions. One may note from Table 3 that the same set of important parameters for all the cases is retained. There are few cases of swapping of the ranking of the parameter importance, e.g., for BIOMIX in SRC. The influence of these parameters in sediment yield is well documented in Neitsch et al. (2005) and Ndomba (2007). Besides, the independently performed simulation results for catchment sediment management scenarios in the study cases indicate that all sorts of farming practices as captured by the PUSLE and $\mathrm{C}_{\text {USLE }}$ parameters (Table 3 ) are the main determinants in reducing soil loss and sediment yield in the upland catchments and subsequent sedimentation problems in the downstream reservoirs (Endale, 2008). The results also suggest that micro river channels also act as important sources of sediment as represented by the high rank of the linear re-entrainment parameter for channel sediment routing factor, Csp. It should be noted that many other factors affect the sediment yield estimations. For instance, the hydrological parameters seem to have a high effect as well on the sediment computations (Ndomba, 2007). This may be explained by the fact that one of the parameters/factors in the sediment yield equation, the

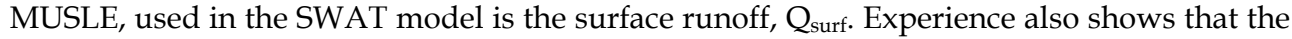
resolution of DEM and the monthly average rainfall intensities, which are provided in the weather generator database are fundamental and crucial. The results in Table 3 below compare well with that of Shimelis et al. (2010) who worked in Angeni Gauged watershed, Ethiopia. In their case the ranking for $\mathrm{Csp}$ and $\mathrm{CCH}$ are first and second, respectively, with $\mathrm{C}_{\text {USLE }}$ ranked in the sixth position.

\begin{tabular}{|c|c|c|c|c|c|}
\hline $\mathrm{SN}$ & Parameter & Description of parameter & $\begin{array}{l}\text { NYM } \\
\text { Rank }\end{array}$ & $\begin{array}{c}\text { SRC } \\
\text { Rank }\end{array}$ & $\begin{array}{l}\text { KRC } \\
\text { Rank }\end{array}$ \\
\hline 1. & Csp & $\begin{array}{l}\text { Linear re-entrainment parameter for } \\
\text { channel sediment routing }\end{array}$ & 1 & 2 & 1 \\
\hline 2. & $\mathrm{CCH}$ & Channel cover factor & 2 & 5 & 2 \\
\hline 3. & Pusle & USLE support practice factor & 3 & 3 & 3 \\
\hline 4. & $\mathrm{KCH}$ & Channel erodibility factor $[\mathrm{cm} / \mathrm{h} / \mathrm{Pa}]$ & 4 & 6 & 4 \\
\hline 5. & SPEXP & $\begin{array}{l}\text { Exponential re-entrainment parameter } \\
\text { for channel sediment routing }\end{array}$ & 5 & 4 & 5 \\
\hline 6. & Cusle & Minimum USLE cover factor & 6 & 7 & 6 \\
\hline 7. & BIOMIX & Biological mixing efficiency. & 7 & 1 & 7 \\
\hline 8. & $\mathrm{~K}_{\text {USLE }}$ & $\begin{array}{l}\text { USLE soil erodibility factor } \\
\text { [t.ha.h./(ha.MJ.mm] }\end{array}$ & 10 & 10 & 10 \\
\hline 9. & RSDIN & Initial residue cover $[\mathrm{kg} / \mathrm{ha}]$ & 10 & 10 & 10 \\
\hline
\end{tabular}

Table 3. Sensitivity analysis results of sediment component of SWAT for three study cases, i.e., NYM, SRC and KRC

\subsection{Model performance}

The discussion in this section focuses on the study cases where there was relatively adequate data and where more modelling efforts were applied (Table 4). For instance, in $\mathrm{KRC}$ the results of the model performance according to $\mathrm{CE}$ for flow calibration and 
validation are 68 and $63 \%$, respectively. For sediment calibration and validation, CE is 66 and $68 \%$, respectively. The calibration and validation results have shown that measured and simulated values were closely related with RE of $7.5 \%$.

The sediment yield calibration results for SRC for the period from 1970 to 1975 in daily and monthly aggregated outputs are presented in Table 4 and Figure 2. The result from the SWAT model at a daily time step is fair with the model performance of $C E=24 \%$. The sediment loads in the peak flood events such as those in 1970, 1972 and 1974 are overpredicted. However, the performance of the model when looking at the monthly sediment loads is good, with $\mathrm{CE}=83 \%$. The sediment modelling was validated for the period between 1976 to 1978 (Figure 3). Daily sediment load is fairly simulated with a model performance of $\mathrm{CE}=16 \%$. Sediment loads during the peak flood events are over-predicted such as in the months of April, 1976 and November, 1978. On the other hand, it under-predicted the loads in January and April of 1977. However, the performance of the model in simulating monthly sediment loads is good with $\mathrm{CE}=80 \%$. The improvement of the SWAT model performance when aggregating the outputs over a longer time period has also been observed by other researchers in the region and elsewhere (Schmidt and Volk, 2005; Shimelis et al., 2010).

Since the routing models for the SWAT model as well as the coupled SWAT-SOBEK models have shown to give acceptable and comparable results, the uncertainty of the sediment routing component has been evaluated to be minimal (Abdelhamid, 2010). The performance was measured against total sediment loads transported to the main outlet of the catchment. A similar result was obtained by Andualem and Yonas (2008) in Ethiopia where they applied SWAT and CCHE1D sediment transport models together in tandem. In Figure 4 shows that simulated and observed annual sediment loads are comparable for Case study 1 , the Koka Reservoir catchment.

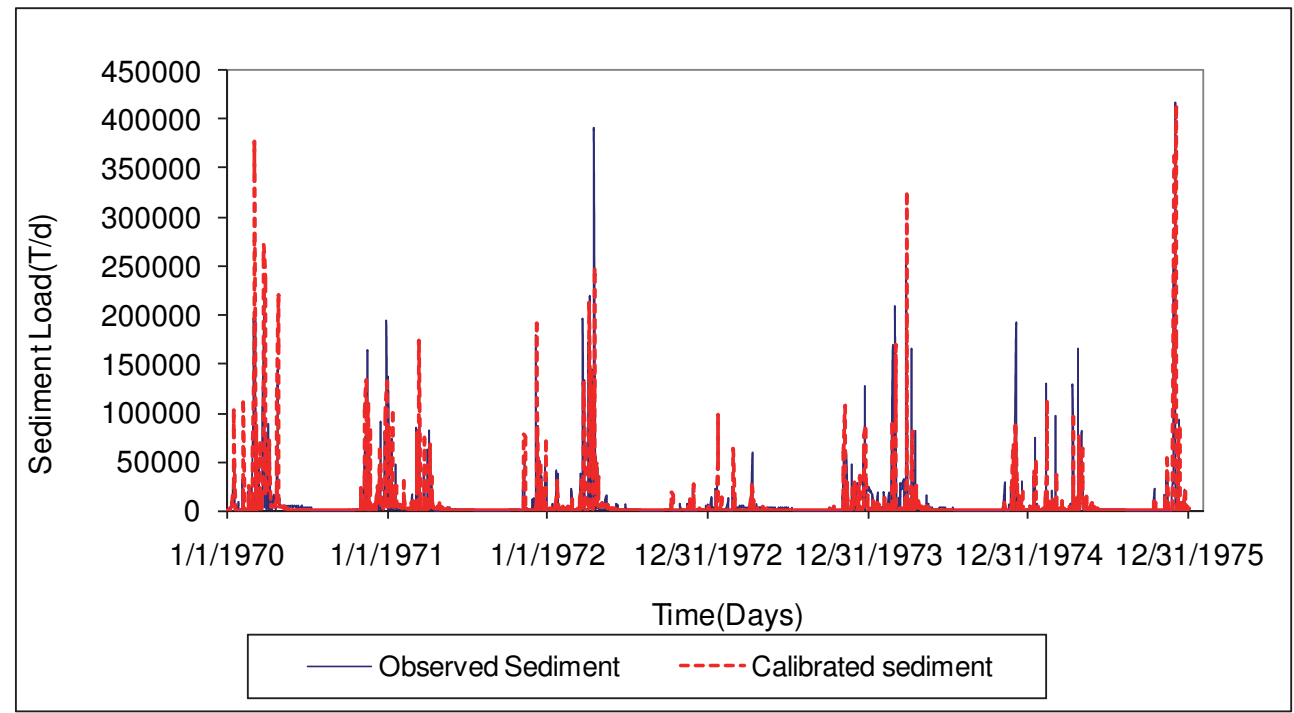

Fig. 2. Comparison between "observed" and simulated Simiyu daily sediment for calibration period from 1970and 1975 at Main Bridge outlet (Abdelhamid, 2010). 


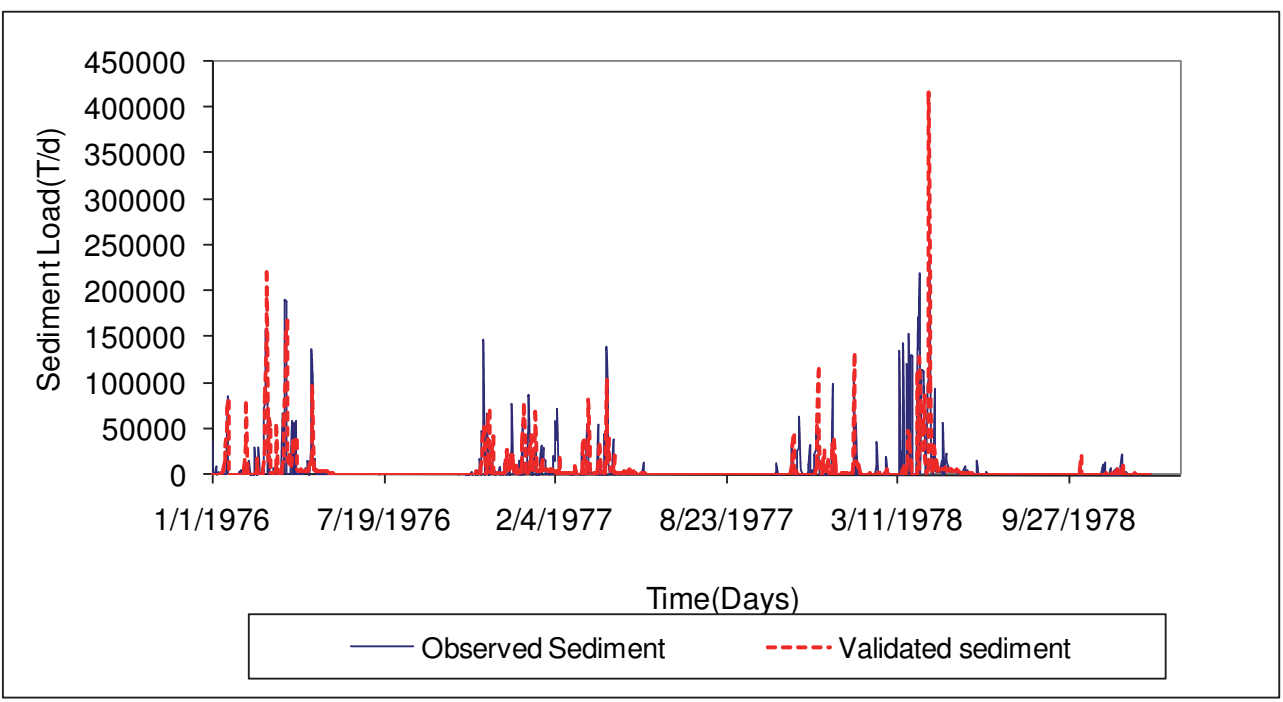

Fig. 3. Comparison between "observed" and simulated Simiyu daily sediment for the validation period from 1976 and 1978 at Main Bridge outlet (Abdelhamid, 2010)

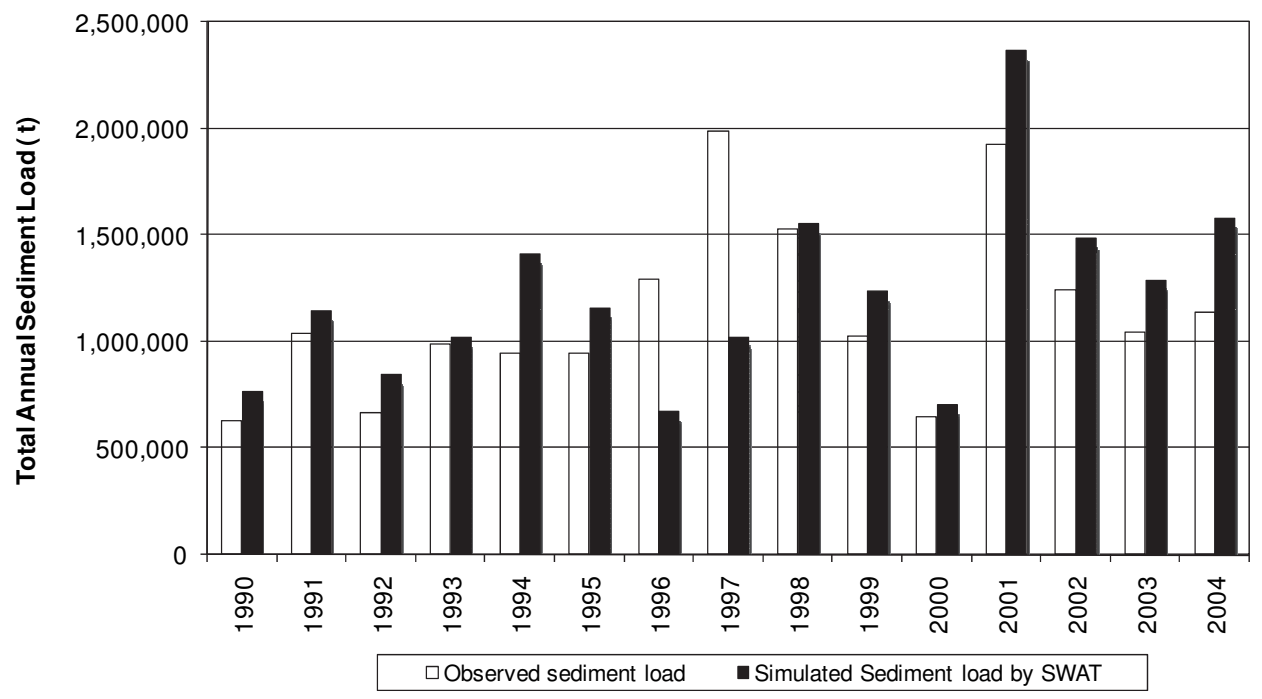

Fig. 4. SWAT simulations vs observed annual sediment loads at Case study 1 , the Koka Reservoir, between 1990 and 2004 (As adopted from Endale, 2008) 


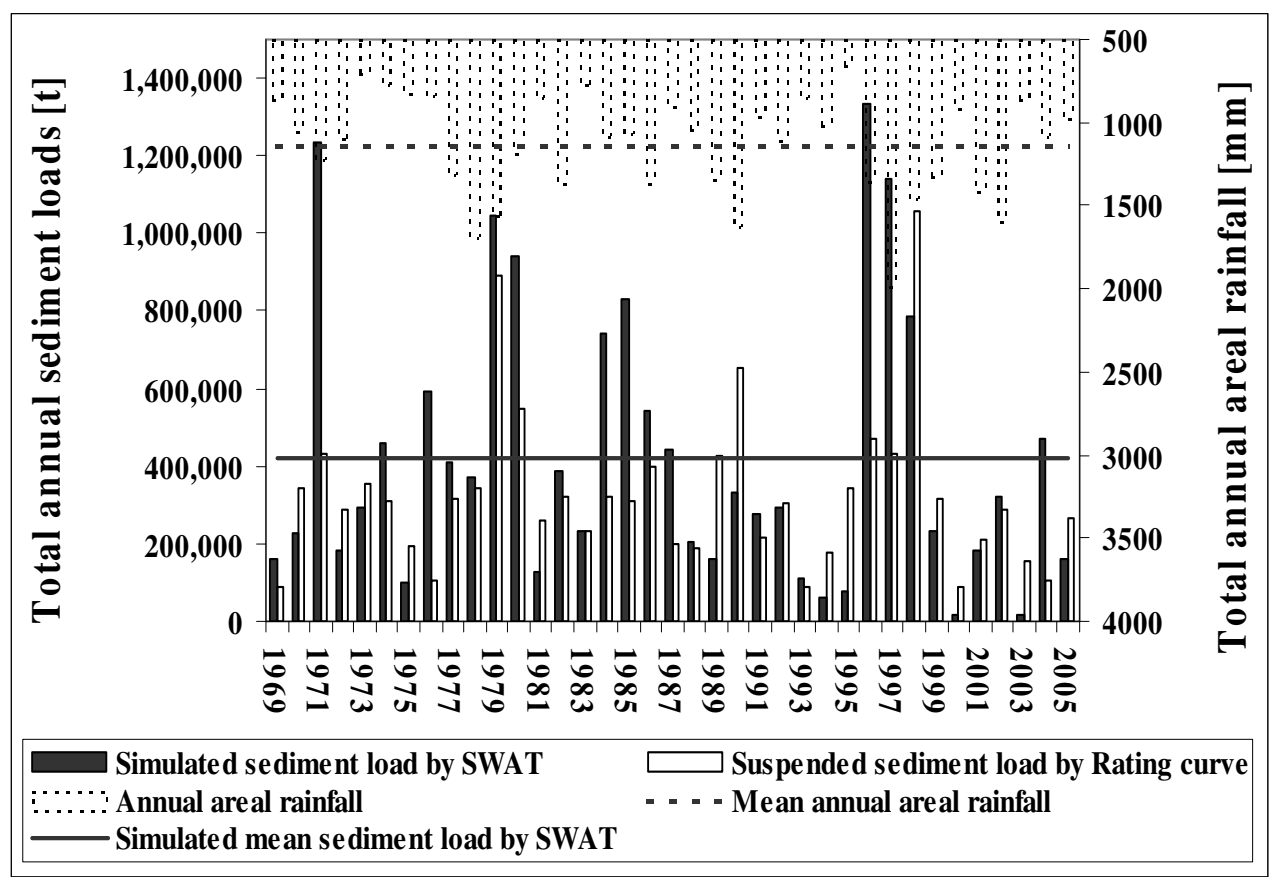

Fig. 5. SWAT simulations vs "observed", rating curve based sediment loads at 1DD1 (annually), between January, 1969 - December, 2005 (Ndomba et al., 2008b)

For the case of the NYM Reservoir catchment the SWAT model captured 56 percent of the variance (CE) and underestimated the observed daily sediment loads by 0.9 percent according to TMC performance indices during a normal wet hydrological year, i.e., with a calibration period set between November 1, 1977 and October 31, 1978 (Table 4). The SWAT model predicted satisfactorily the long-term sediment catchment yield with a relative error of 2.6 percent (Table 4 \& Figure 5). It should be noted that the "observed" sediment loads were estimated from the bias-corrected suspended sediment rating curve. Authors are aware that the SWAT model simulates bed-material load (i.e. bed and suspended load) while the rating curve computes only suspended sediment load. However, it should be noted that the sediment loads delivered to streams are characterized as fine (Ndomba, 2007). They would mostly be transported as suspended sediments loads. The accuracy achieved by using the SWAT model was expected because it was hypothesized that correct estimation of surface runoff would lead to a better prediction of the sediment yield. Other researchers such as Garde and Ranga Raju (2000) are of similar opinion. Also, the model has identified erosion sources spatially and has replicated some erosion processes as determined in other studies and field observations in the NYM (Ndomba et al., 2008b). This result suggests that for catchments where sheet erosion is dominant, the SWAT model may substitute other sediment yield estimation methods such as the sediment-rating curve. However, SWAT model simulations results for sediment storage in a reach such as the 1DD1 gauging station in the Myumba Ya Mungu Reservoir catchment differ from the findings based on other 
approaches, , i.e., field observations and analysis of field-based sediment flow data. It was observed that the SWAT model could not capture the dynamics of sediment load delivery in some seasons to the catchment outlet (Ndomba et al., 2008b). The reach is known to transport most of the sediment loads delivered from the catchment (i.e. equilibrium river reach). The particular study linked the latter problem to model deficiency. The authors would like to note that it is difficult to compare the model performance objectively as the quality and quantity of data used are different. Notwithstanding, there is a general agreement on the performance based on the cumulative sediment yield amount as measured by a relative error below 20 percent for both (Table 4). It could also be observed that the catchment size and climate are relatively similar. However, there are differences in catchment characteristics, i.e. geology, soils type, and topography.

\begin{tabular}{|c|c|c|c|c|c|}
\hline \multirow{2}{*}{ Variables } & \multirow{2}{*}{ Performance indicators } & \multirow{2}{*}{ Time step } & \multicolumn{3}{|c|}{ Study cases } \\
\hline & & & KRC & NYM & SRC \\
\hline \multirow{5}{*}{ Runoff } & \multirow{2}{*}{ Calibration, CE (\%) } & Daily & 68 & 54.6 & 38 \\
\hline & & Monthly & - & 65 & 82 \\
\hline & \multirow{2}{*}{ Validation, CE (\%) } & Daily & 63 & 68 & 30 \\
\hline & & Monthly & - & 77.4 & 81 \\
\hline & IVF (\%) & & - & 100 & 104 \\
\hline \multirow{5}{*}{$\begin{array}{l}\text { Sediment } \\
\text { yield rate }\end{array}$} & \multirow{2}{*}{ Calibration, CE $(\% \backslash)$} & Daily & 66 & 56 & 24 \\
\hline & & Monthly & & - & 83 \\
\hline & \multirow{2}{*}{ Validation, CE (\%) } & Daily & 68 & - & 16 \\
\hline & & Monthly & - & - & 80 \\
\hline & Relative Error, (RE) (\%) & & 7.5 & 2.6 & 0.76 \\
\hline
\end{tabular}

Table 4. SWAT model performance for the 3 study cases, i.e., KRC, NYM and SRC Note: "-" not evaluated as a result of missing data.

From the engineering perspective, sediment yield information is critical to estimating the design life of a reservoir as a result of sedimentation. A lumped spatial and temporal scales model could serve this purpose. However, if further insights into erosion processes and sediment sources are sought then finer temporal and spatial scales are important, e.g., to evaluate best management practices, effects of land use and effects of land cover change. Besides, as the overall objective of this paper is to critically assess the suitability of the SWAT model for sediment yield modeling, various components and/or functionalities were evaluated. As presented earlier in this chapter, the SWAT model predicted satisfactorily the cumulative long-term sediment catchment yield, and the performance was measured using Relative Error (RE) in percent.

The performances of the SWAT model in the study cases and others conducted in catchments of the Eastern Africa as reported in literatures based on CE and IVF and Relative 
Errors (RE) criteria suggest that the model can fairly/satisfactorily estimate sediment yield for even poorly gauged catchments (Ndomba et al., 2005; Ndomba, 2007; Mulungu and Munishi, (2007); Ndomba and Birhanu, 2008; Ndomba et al., 2008b; Andualem and Yonas, 2008; Shimelis et al., 2010). The latter mainly proves that the models are able to capture the dynamics in time, but it provides little validation on the identification of the processes and/or the parameters in space which would require observations at several internal points in the catchment.

\section{Conclusions and recommendations}

\subsection{Conclusions}

This chapter presents three study cases in Eastern Africa where the SWAT model was applied extensively using the available data. In few cases primary data on sediment loads were explored. These cases represent various climatic conditions within the equatorial and/or tropical region. Based on the results of this study, the SWAT model seems to be robust and can be relied upon as a tool for catchment sediment management in the tropics. However, the model could not capture dynamics of sediment load delivery (i.e. equilibrium river regime) in some seasons in one catchment. The particular study linked the latter problem to model deficiency. Based on the simulation results the study has found that all sorts of farming practices captured by PUSLE and CUSLE parameters are the main determining management techniques in reducing soil loss/sediment yield and subsequently sedimentation problems in the reservoir. Besides, the performances of the SWAT model in these study cases as well as others conducted in Eastern Africa suggest that the model can satisfactorily estimate sediment yield for even poorly gauged catchments. The temporal variability is quite well captured. It should be noted that the calibration of the distributed parameters was typically done in a "lumped" way using sediment observations at the outlet instead of using observations at interior locations in the river basin. Therefore, the physical meaning of these parameters as well as the spatial representativeness could be questioned. The performance of the model suggests that the model can be used as a research tool in reservoir sedimentation and sediment yield modelling studies in the region.

The results of these study cases are not conclusive enough because some challenges have not been addressed. Although the input data varies in type and quality, from coarse-resolution to high-resolution measured spatial and climate data, there is a general lack of highresolution spatial input data. More high-resolution spatial input data may not necessarily improve the performance of the model, but it may contribute to a better representation of the spatial variability. For erosion modelling, a high DEM resolution is especially important because the DEM is used to compute the slopes. Slopes have dual role: they affect the runoff processes in the hydrology that directly influence the erosion computations, and they are also directly used in the MUSLE equation.

It should be noted that the authors are aware that the performance of the SWAT model applications in the study cases can not be compared objectively because the performance is affected by modelling efforts and techniques, input data quality and catchment representation of important hydrological features.

\subsection{Recommendations}

A general recommendation is that more attention needs to be given to the spatial representativeness of the processes, the process parameters and the input data. The latter involves: 
i. Move from a rather "lumped calibration" on data at the outlet to a more distributed calibration by using internal gauging data for both flow, sediments and rainfalls. This can also be achieved through using higher resolution data, especially for DEM but also the land use and soil maps;

ii. Improving the representation of important hydrological features, especially the water ponds, wetlands/marsh or swamps;

iii. Improve the routing component of the model. In some cases the SWAT model simulations indicated sediment storage in a river reach to be unlike the findings based on other approaches.

It is important to continue efforts in applying SWAT in Eastern Africa. However, the authors appeal to those who want to apply SWAT in their studies is not to apply it blindly. They need to consult experience from previous studies in Eastern Africa.

\section{Acknowledgements}

This work was co-funded by The Norwegian Programme for Development, Research and Education (NUFU) - Water Management in Pangani River Basin Tanzania Project at University of Dar es Salaam, Nile Basin Capacity Building Network-River Engineering Initiative, FRIEND/Nile based at UNESCO - Cairo Office in Cairo, Egypt and UNESCO-IHE Partnership Research Fund (UPaRF) through Adaptation to Climate Change Impacts on the Nile River Basin (ACCION) project. In addition, the authors wish to express their gratitude to Mr. F. Mashingia, a PhD fellow at University of Dar es Salaam, for preparing study area maps, as well as to anonymous reviewers, who helped to improve this chapter through their thorough review

\section{References}

Abbaspour, K.C., Johnson, C.A., van Genuchten, M.T., (2004). Estimating uncertain flow and transport parameters using a sequential uncertainty fitting procedure. Vadose Zone J. 3, 1340-1352.

Abbaspour, K.C., Yang, J., Maximov, I., Siber, R., Bogner, K., Mieleitner, J., Zobrist, J., Srinivasan, R., (2007). Modelling of hydrology and water quality in the prealpine/alpine Thur watershed using SWAT. J. Hydrol. 333, 413-430.

Abdelhamid, M.R., (2010). Sediment Transport Modelling in Simiyu Catchment of Lake Victoria Basin, Tanzania. MSc Thesis WSE-HI.10-06. UNESCO-IHE, Institute for Water Education, Netherlands.

Arnold, J.G., Williams, J.R., \& Maidment, D.R., (1995). Continuous-time water and sedimentrouting model for large basins. Journal of Hydraulic Engineering, Vol. 121(2): pp. 171183.

Bagnold, R.A., (1977). Bedload transport in natural rivers. Water Resour. Res. 13:303-312.

Bathurst, J.C., (2002). Physically-based erosion and sediment yield modelling: the SHETRAN concept. In: Wolfgang Summer and Desmond E.Walling (ed.), Modelling erosion, sediment transport and sediment yield. IHP-VI Technical Documents in Hydrology, No.60, pp47-68.

De Pauw, E. (1984). Soils, Physiography and Agro ecological zones of Tanzania Publication: Crop monitoring and early warning systems Project GCPS/URT/047/NET. Ministry of 
Agriculture, Dar es Salaam Food and Agriculture Organization of the United Nations.

Duan, Q.D., Gupta, V.K. and Sorooshian, S., (1992). Effective and efficient global optimization for conceptual rainfall-runoff models. Water Resources Research 28(4), pp 1015-1031.

Endale, B.A., (2008). Application of SWAT model in studying sedimentation problems in the reservoirs and proposing possible mitigation measures. A case of Koka reservoir, Ethiopia. MSc Dissertation. University of Dar es Salaam.

Ferguson, R.I., (1986) River loads underestimated by rating curves. Water Resour. Res. 22(1), 74-76.

Hathout, S.A., (1983). Soil Atlas of Tanzania. Tanzania Publishing House, Dar es Salaam

Lawrence, P., Cascio, A., Goldsmith, O., \& Abott, C.L., (2004). Sedimentation in small dams - Development of a catchment characterization and sediment yield prediction procedure. Department For International Development (DFID) Project R7391 HR Project MDS0533 by HR Wallingford.

Lemma G., (1996), Climate Classifications of Ethiopia. National Meteorological Services Agency, Addis Ababa, Ethiopia.

Melching, C.S., (1995). Reliability estimation. In Computer Models of Watershed Hydrology by V.P. Singh, (eds), Water Resources Publications, pp69-118.

Morris, G. \& Fan, J., (1998). Reservoir sedimentation Handbook: Design and Management of Dams, Reservoirs and Catchment for Sustainable use. McGrawHill, New York. Chapter 7, pp7.1-7.44.

Morris, M.D., (1991). Factorial Sampling Plans for Preliminary Computational Experiemnts. Technometrics, 33(2), 161-174.

Mulengera, M.K., and Payton, R.W., (1999). Estimating the USLE-Soil erodibility factor in developing tropical countries. Trop. Agric. (Trinidad) Vol. 76 No. 1, pp17-22.

Ndomba, P.M., Mtalo, F. \& Killingtveit, A., (2005). The Suitability of SWAT Model in Sediment Yield Modelling for Ungauged Catchments. A Case of Simiyu Subcatchment, Tanzania. Proceedings of the $3^{\text {rd }}$ International SWAT conference, pp6169. EAWAG-Zurich, Switzerland, 11th -15 th July 2005, Sourced at http://www.brc.tamus.edu/swat.

Ndomba, P.M., (2007). Modelling of Erosion Processes and Reservoir Sedimentation Upstream of Nyumba ya Mungu Reservoir in the Pangani River Basin. A PhD Thesis (Water Resources Engineering) of University of Dar es Salaam.

Andualem G. \& Yonas M. (2008). Prediction of Sediment Inflow to Legedadi Reservoir Using SWAT Watershed and CCHE1D Sediment Transport Models. Nile Basin Water Engineering Scientific Magazine, Vol.1, (2008), pp 65-74.

Ndomba, P.M., Mtalo, F.W., and Killingtveit, A., (2008a). Developing an Excellent Sediment Rating Curve From One Hydrological Year Sampling Programme Data: Approach. Journal of Urban and Environmental Engineering, V.2,n.1,p.21-27. ISSN 1982-3932, doi:10.4090/juee.2008.v2n1.021027

Ndomba, P.M., Mtalo, F.W., and Killingtveit, A., (2008b). A Guided SWAT Model Application on Sediment Yield Modelling in Pangani River Basin: Lessons Learnt. Journal of Urban and Environmental Engineering, V.2,n.2,p.53-62. ISSN 1982-3932, doi:10.4090/juee.2008.v2n2.053062. 
Ndomba, P.M. \& Birhanu, B.Z., (2008). Problems and Prospects of SWAT Model Applications in Nilotic Catchments: A Review. Nile Basin Water Engineering Scientific Magazine, Vol.1, (2008), pp 41-52.

Ndomba, P.M., Mtalo, F., and Killingtveit, A., (2009). Estimating Gully Erosion Contribution to Large Catchment Sediment Yield Rate in Tanzania. Journal of Physics and Chemistry of the Earth 34 (2009) 741 - 748. DOI: 10.1016/j.pce.2009.06.00. Journal homepage: www.elsevier.com/locate/pce.

Neitsch, S.L., Arnold, J.G., Kiniry, J.R., \& Williams, J.R., (2005). Soil and Water Assessment Tool Theoretical Documentation Version 2005. Grassland, Soil and Water Research Laboratory; Agricultural Research Service 808 East Blackland Road; Temple, Texas 76502; Blackland Research Research Center; Texas Agricultural Experiment Station 720 East Blackland Road; Temple, Texas 76502, USA.

Rohr, P.C., \& Killingtveit, A., (2003). Rainfall distribution on the slopes of Mt. Kilimanjaro. Journal of Hydrological Sciences, 48(1):65-77

SCS (USDA Soil Conservation Service), (1972). National Engineering Handbook Section 4: Hydrology, Chapters 4-10.

Shimelis G. Setegn, Bijan Dargahi, Ragahavan Srinivasan, and Assefa M. Melesse (2010). Modelling Of Sediment Yield From Anjeni-Gauged Watershed, Ethiopia Using SWAT Model. Journal of The American Water Resources Association, Vol. 46, No. 3, pp 514-526.

Schmidt, G. \& Volk, M., (2005) Effects of input data resolution on SWAT simulations - A case study at the Ems river basin (Northwestern Germany). Proc. 3rd Int. SWAT conf., 241-250. EAWAG-Zurich, Switzerland, 11-15 July 2005, Sourced at http://www.brc.tamus.edu/swat.

Summer, W., Klaghofer, E., Abi-zeid, I., \& Villeneuve, J.P., (1992). Critical reflections on long term sediment monitoring programmes demonstrated on the Austrian Danube. Erosion and Sediment Transport Monitoring Programmes in River Basins. Proceedings of the Oslo Symposium, August 1992. IAHS Publ. No. 210, pp.255-262.

Van Liew, M.W., Arnold, J.G., \& Bosch, D.D., (2005). Problems and Potential of Autocalibrating a Hydrologic Model. Soil \& Water Division of ASAE, Vol.48 (3):pp1025-1040.

Van Griensven, A., and Srinivasan, R., (2005). AVSWATX SWAT-2005 Advanced Workshop workbook. SWAT2005 3rd international conference, July 11-15, 2005, Zurich, Switzerland.

Vanoni, V.A. (eds), (1975). Sedimentation Engineering. Prepared by the ASCE Task Committee for the preparation of the manual on sedimentation of the sedimentation committee of the Hydraulic Division. Copyright 1975 by the American Society of Civil Engineers. Library of Congress Catalog Card Number: 75-7751. ISBN_0-87262-001-8.

Wasson, R.J., (2002). What approach to the modelling of catchment scale erosion and sediment transport should be adopted? In: Wolfgang Summer and Desmond E.Walling (ed.), Modelling erosion, sediment transport and sediment yield. IHP-VI Technical Documents in Hydrology, No.60, pp1-12

Williams, J.R., (1975). Sediment-yield prediction with universal equation using runoff energy factor. In: Present and prospective technology for predicting sediment yield and 
sources: Proceedings of the sediment-yield workshop, USDA Sedimentation Lab., Oxford, MS, November 28-30, 1972. ARS-S-40.

Yapo, P.O., Gupta, H.V., \& Sorooshian, S., (1996). Automatic calibration of conceptual rainfall-runoff models: sensitivity to calibration data. Journal of Hydrology, vol.181, pp23-48. 


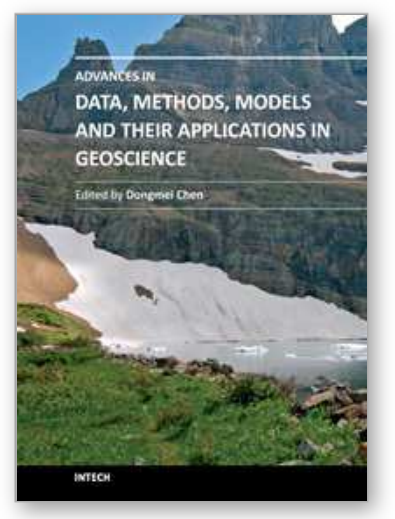

\section{Advances in Data, Methods, Models and Their Applications in Geoscience}

Edited by Dr. DongMei Chen

ISBN 978-953-307-737-6

Hard cover, 336 pages

Publisher InTech

Published online 22, December, 2011

Published in print edition December, 2011

With growing attention on global environmental and climate change, geoscience has experienced rapid change and development in the last three decades. Many new data, methods and modeling techniques have been developed and applied in various aspects of geoscience. The chapters collected in this book present an excellent profile of the current state of various data, analysis methods and modeling techniques, and demonstrate their applications from hydrology, geology and paleogeomorphology, to geophysics, environmental and climate change. The wide range methods and techniques covered in the book include information systems and technology, global position system (GPS), digital sediment core image analysis, fuzzy set theory for hydrology, spatial interpolation, spectral analysis of geophysical data, GIS-based hydrological models, high resolution geological models, 3D sedimentology, change detection from remote sensing, etc. Besides two comprehensive review articles, most chapters focus on in-depth studies of a particular method or technique.

\section{How to reference}

In order to correctly reference this scholarly work, feel free to copy and paste the following:

Preksedis Marco Ndomba and Ann van Griensven (2011). Suitability of SWAT Model for Sediment Yields Modelling in the Eastern Africa, Advances in Data, Methods, Models and Their Applications in Geoscience, Dr. DongMei Chen (Ed.), ISBN: 978-953-307-737-6, InTech, Available from:

http://www.intechopen.com/books/advances-in-data-methods-models-and-their-applications-ingeoscience/suitability-of-swat-model-for-sediment-yields-modelling-in-the-eastern-africa

\section{INTECH}

open science | open minds

\section{InTech Europe}

University Campus STeP Ri

Slavka Krautzeka 83/A

51000 Rijeka, Croatia

Phone: +385 (51) 770447

Fax: +385 (51) 686166

www.intechopen.com

\section{InTech China}

Unit 405, Office Block, Hotel Equatorial Shanghai

No.65, Yan An Road (West), Shanghai, 200040, China 中国上海市延安西路65号上海国际贵都大饭店办公楼 405 单元

Phone: +86-21-62489820

Fax: $+86-21-62489821$ 
(C) 2011 The Author(s). Licensee IntechOpen. This is an open access article distributed under the terms of the Creative Commons Attribution 3.0 License, which permits unrestricted use, distribution, and reproduction in any medium, provided the original work is properly cited. 